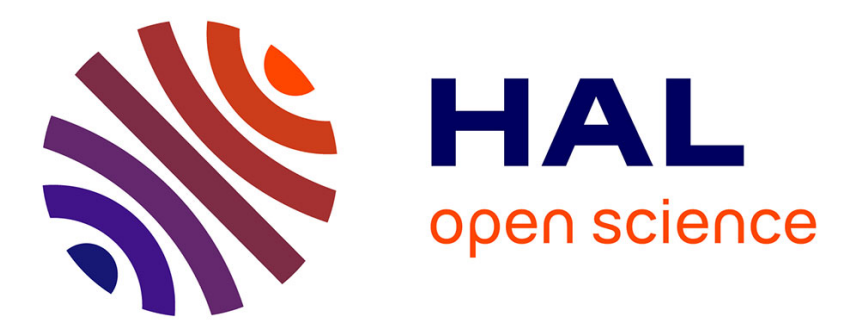

\title{
Structure development during polymer processing. Morphological and crystallographic textures in polyethylene blown films
}

Jean-Marc Haudin, Jean-Marc Andre, Gaëlle Bellet, Bernard Monasse, Patrick Navard

\section{To cite this version:}

Jean-Marc Haudin, Jean-Marc Andre, Gaëlle Bellet, Bernard Monasse, Patrick Navard. Structure development during polymer processing. Morphological and crystallographic textures in polyethylene blown films. Revue de Métallurgie, 2002, 29 (12), pp.Pages 1097-1104. 10.1051/metal:2002155 . hal-00572498

HAL Id: hal-00572498

https://hal-mines-paristech.archives-ouvertes.fr/hal-00572498

Submitted on 9 Mar 2012

HAL is a multi-disciplinary open access archive for the deposit and dissemination of scientific research documents, whether they are published or not. The documents may come from teaching and research institutions in France or abroad, or from public or private research centers.
L'archive ouverte pluridisciplinaire HAL, est destinée au dépôt et à la diffusion de documents scientifiques de niveau recherche, publiés ou non, émanant des établissements d'enseignement et de recherche français ou étrangers, des laboratoires publics ou privés. 


\title{
Structure development during polymer processing. Morphological and crystallographic textures in polyethylene blown films
}

\author{
J.-M. Haudin, J.-M. André, G. Bellet, \\ B. Monasse, P. Navard \\ École des Mines de Paris, Centre de Mise en Forme \\ des Matériaux, UMR 7635, Sophia Antipolis
}

\begin{abstract}
The crystallographic texture of a great number of polyethylene films manufactured by the film blowing process has been investigated by X-ray diffraction. Some films present a classical texture (c-axis in the machine direction), which can be interpreted using existing morphological models. Other exhibit an original texture (c-axis in the film thickness) and no satisfactory morphological model has been proposed until now.
\end{abstract}

\section{INTRODUCTION}

Structure (or microstructure) development is more and more a key issue in polymer processing in view of controlling the final properties of the product. A major component of structure development is crystallization, which generally occurs in complex conditions : rapid cooling and temperature gradients, flow, surface effects due to processing tools (1). As in metallurgy, the final microstructure can be described at different levels :

- the level of the morphological texture, i.e. the arrangements of polymer crystals separated by amorphous layers ;

- the level of the crystallographic texture, also called crystalline orientation, i.e. the orientation of the crystal unit cells, which must be combined with the average orientation of the amorphous phase.

These two levels are interrelated in a complex way, as will be shown in the case of film blowing.

Manuscrit reçu le 26 février 2001, bon à publier le 2 août 2002.

(c) La Revue de Métallurgie 2002.
Film blowing is the main process to manufacture polymer films (fig. 1). It is essentially dedicated to polyethylene, especially for packaging applications. In this process, the polymer melt is extruded through an annular die, and then simultaneously inflated by a certain volume of air entrapped in the bubble and drawn by nip rolls. Cooling is achieved by blowing air through a ring located outside the bubble. In recent technological developments, the film can be also cooled from inside with the help of a cooling mandrel, or from outside but with sophisticated double-flux air rings. Due to cooling, the polymer is solidified at a certain height, which means partly crystallized. Once the film is solidified, it is pulled, folded and wound on cylindrical cores.

In the film blowing process, the polymer is subjected to a biaxial stretching due to the effect of longitudinal and transverse stresses. This induces an orientation of macromolecules in the melt. After solidification, this orientation is partly



Figure 1 - Schematic diagram of the film blowing process.

Figure 1 - Schéma du procédé de soufflage de gaine. 


\title{
Développement de structure en mise en forme des polymères. Textures morphologiques et cristallographiques dans les gaines de polyéthylène soufflées
}

\author{
J.-M. Haudin, J.-M. André, G. Bellet, B. Monasse, P. Navard \\ École des Mines de Paris, Centre de Mise en Forme des Matériaux, \\ UMR 7635, Sophia Antipolis
}

En mise en forme des polymères, la compréhension du développement de la microstructure apparaît de plus en plus comme une étape clé pour le contrôle des propriétés finales du produit. Pour de nombreux polymères, la cristallisation, qui se produit généralement dans des conditions complexes (écoulement, fortes vitesses de refroidissement et gradients thermiques, effet de la paroi des outillages), est une composante essentielle du développement de structure. Comme en métallurgie, la microstructure finale peut être définie à différents niveaux :

- le niveau de la texture morphologique, c'est-à-dire la description des arrangements de cristaux séparés par de la phase amorphe ;

- le niveau de la texture cristallographique (orientation des mailles cristallines), à combiner avec l'orientation de la phase amorphe.

Ces deux niveaux sont bien sûr liés mais de façon parfois complexe, comme le montre le procédé de soufflage de gaine.

Dans le procédé de soufflage de gaine, le polymère fondu est extrudé à travers une filière annulaire qui lui donne la forme d'un tube. Ce tube est étiré longitudinalement par un système de rouleaux pinceurs. Un certain volume d'air emprisonné à l'intérieur de la gaine assure son gonflage, c'est-à-dire son étirage transversal. À partir d'une certaine hauteur, dite hauteur de figeage, elle est solidifiée. Le développement de la microstructure s'effectue donc dans des conditions mécaniques et thermiques particulièrement complexes.

Trois séries de films différant par la nature du polymère (polyéthylène basse densité (PEBD), polyéthylène basse densité linéaire (PEBDL), PEBDL obtenu par catalyse métallocène) ont été étudiées. La texture cristallographique de ces films a été caractérisée par des figures de pôles, à partir desquelles ont été calculées les fonctions d'orientation biaxiale de White-Spruiell. Ce sont des combinaisons des cosinus carrés des angles entre une direction caractéristique du procédé $i$ ( $i$ = direction machine DM, direction transverse $D T$ ) et un axe cristallographique $j(j=$ $\boldsymbol{a}, \boldsymbol{b}, \boldsymbol{c})$. Les résultats sont présentés sous forme de diagrammes triangulaires dans lesquels l'origine représente l'isotropie ; les points $(0,1),(1,0)$ et $(-1,-1)$ représentent des orientations uniaxiales parfaites selon DM, DT et la normale au film $D N$; la première bissectrice correspond à une orientation équibiaxiale.

Dans la première série de films, les chaînes sont préférentiellement orientées selon DM dans la phase cristalline et selon DT dans la phase amorphe. La seconde série montre l'importance des conditions de refroidissement. Si un anneau à simple flux d'air est utilisé, la texture cristalline est analogue à celle de la première série. Au contraire, avec un anneau à double flux, une nouvelle texture, caractérisée par l'axe c préférentiellement dans l'épaisseur du film, apparaît, aussi bien pour un PEBD que pour un $P E B D L$. La troisième série compare différents $P E B D L$. Une fois de plus, l'axe c de la maille cristalline est orienté dans l'épaisseur du film, tandis que la phase amorphe est répartie de façon isotrope dans son plan.

Les orientations quasi uniaxiales selon DM peuvent être interprétées à l'aide des modèles morphologiques existant dans la littérature (gerbes, cylindrites). En revanche, les textures exhibant un axe c dans l'épaisseur sont originales et aucun modèle morphologique n'a jusqu'à présent été proposé pour leur interprétation. Pour aider à cette interprétation, la surface des films de la troisième série a été observée par microscopie électronique à balayage. Ces observations n'ont toutefois pas permis de lever l'apparente contradiction entre texture cristallographique et texture morphologique. frozen in the amorphous phase. On the other hand, molecular orientation has an influence on nucleation and growth of crystals. Therefore, a major effect of processing is to create orientation both in the crystalline and amorphous phases.

The general objective of the present paper is to characterize crystalline orientation in blown films manufactured in various conditions from different polyethylenes, and to discuss experimental results using morphological models. Additional information concerning the orientation of the amorphous phase will be also provided.

\section{MATERIALS AND METHODS}

\section{Materials and processing conditions}

This paper makes the synthesis of the results obtained on a large number of blown films differing by the nature of the polymer (low-density polyethylene (LDPE), linear low-density polyethylene (LLDPE), metallocene LLDPE) and the processing conditions. The detailed molecular characteristics of the polymers as well as the exact processing conditions of the films are given in (2-6). The films are distributed into three series : 
- series $A$ (2-4) : two LDPE (polymers with long-chain branching) with about the same densities ( $\rho=0.9225 \mathrm{~g} / \mathrm{cm}^{3}$ and $\rho=0.9220 \mathrm{~g} / \mathrm{cm}^{3}$, respectively) but differing by their average molar masses and relaxation times ;

- series $B(5)$ : three polyethylenes with about the same density $\left(\rho=0.920 \mathrm{~g} / \mathrm{cm}^{3}\right)$ - two LDPE obtained either in a batch or in a tubular process, and a LLDPE (with short-chain branching due to copolymerization with a $\mathrm{C}_{6}$ olefin). Extrusion was subsequently achieved using either a pilot set-up with a single-flux air ring or an industrial machine with a single- or double-flux air ring ;

- series $C(6)$ : seven LLDPE differing by the type of catalysts (six Ziegler-Natta and one metallocene) and the type of branching due to copolymerization with various co-monomers : butene-1, hexene-1, 4-methylpentene-1.

The following processing conditions were systematically varied:

- the blow-up ratio (Bur), i.e., the ratio of the final radius of the bubble to the radius of the die ;

- the draw-ratio (Dr), i.e., the ratio of the final velocity to the velocity at the die exit ;

- the freeze line height (Flh), i.e., the height at which matter solidifies. It can be given in $\mathrm{cm}$ or normalized by the radius of the die.

As Bur is dimensionless, it is necessary to know the radius or the diameter of the die to have an idea of the exact size of the bubble. For series $A$ and $C$, the diameter of the die was $100 \mathrm{~mm}$. For series B, it was $50.5 \mathrm{~mm}$ for the pilot setup, and $225 \mathrm{~mm}$ (single-flux) or $150 \mathrm{~mm}$ (double-flux air ring) for the industrial machine.

\section{Film characterization}

In a classical way, the orientation of the crystalline phase was characterized by wide-angle X-ray diffraction. Polyethylene crystallizes in the orthorhombic system. According to Bunn (7), the parameters of the unit cell are $a=0.74 \mathrm{~nm}$, $\mathrm{b}=0.493 \mathrm{~nm}, \mathrm{c}=0.2534 \mathrm{~nm}$. The c-axis is the direction of the macromolecular chains, whereas the $\mathbf{b}$-axis is the growth direction of the crystals. In X-ray diffraction, the main reflections for polyethylene are 110, 200 and 020 . They correspond to crystal planes containing the chain axis. In particular, the 200 reflection corresponds to the diffraction by crystal planes of normal $\mathbf{a}$ and 020 to the diffraction by planes of normal $\mathbf{b}$. Conversely, due to the lack of $00 \ell$ reflection for the polyethylenes under investigation, no direct information on the c-axes is given by $\mathrm{X}$-ray diffraction.

Crystalline orientation was characterized by means of pole figures and orientation factors. Orientation measurements were carried out on rectangular specimens cut out of the blown films with a OXYZ frame of reference, where OX, OY and OZ are the machine (DM), transverse (DT) and normal (DN) directions, respectively. In the case of very thin films, several specimens were cut along the same generatrix of the bubble and stacked in order to obtain measurable diffracted intensities.
These flat samples were mounted on the specimen table of a Huber texture goniometer. CuK $\alpha$ radiation was used.

After the paper of Lindenmeyer and Lustig (8), the use of pole figures to characterize orientation of the crystalline phase in polyethylene films has been generalized (9-16). In combination with pole figure measurements, the average state of orientation can be described by orientation factors, which are simple functions of the squared cosines of the angles $\phi_{\mathrm{j}, \mathrm{i}}$ between a crystallographic axis j ( $\left.=\mathbf{a}, \mathbf{b}, \mathbf{c}\right)$ and a macroscopic axis i (here i denotes DM and DT, respectively). The biaxial orientation factors proposed by White and Spruiell (17) will be used here. They are defined by :

$$
\begin{aligned}
& \mathrm{f}_{\mathrm{j}, \mathrm{DM}}^{\mathrm{B}}=2<\cos ^{2} \phi_{\mathrm{j}, \mathrm{DM}}>+<\cos ^{2} \phi_{\mathrm{j}, \mathrm{DT}}>-1 \\
& \mathrm{f}_{\mathrm{j}, \mathrm{DT}}^{\mathrm{B}}=<\cos ^{2} \phi_{\mathrm{j}, \mathrm{DM}}>+2<\cos ^{2} \phi_{\mathrm{j}, \mathrm{DT}}>-1
\end{aligned}
$$

The $<\cos ^{2} \phi_{\mathrm{j}, \mathrm{i}}>$ for the $\mathbf{a}$ - and $\mathbf{b}$-axes are calculated directly from the pole figures. The values for the c-axis are then deduced from these calculations $(14,15)$. These orientation factors can be expressed in terms of an orientation triangle as shown in figure 2. This triangle is a region in the $\mathrm{f}_{\mathrm{DM}}^{\mathrm{B}}$ vs. $\mathrm{f}_{\mathrm{DT}}^{\mathrm{B}}$ space set about the origin $(0,0)$ and with corners at $(1,0)$, $(0,1)$, and $(-1,-1)$. The origin represents isotropy, while the points $(1,0),(0,1)$ and $(-1,-1)$ correspond to perfect uniaxial orientation in the DM, DT and DN directions, respectively. The first bissector describes states of perfect biaxial orientation.

The global (i.e., crystalline and amorphous) orientation in series $A$ and $C$ films has been characterized by bi- and trirefringence measurements, respectively. Then, the orientation of the amorphous phase has been calculated from these measurements and from the crystalline orientation. The results can be also expressed in the form of biaxial orientation factors (see equations [1] and [2]), where j now denotes the chain axis in the amorphous phase $(4,6)$.

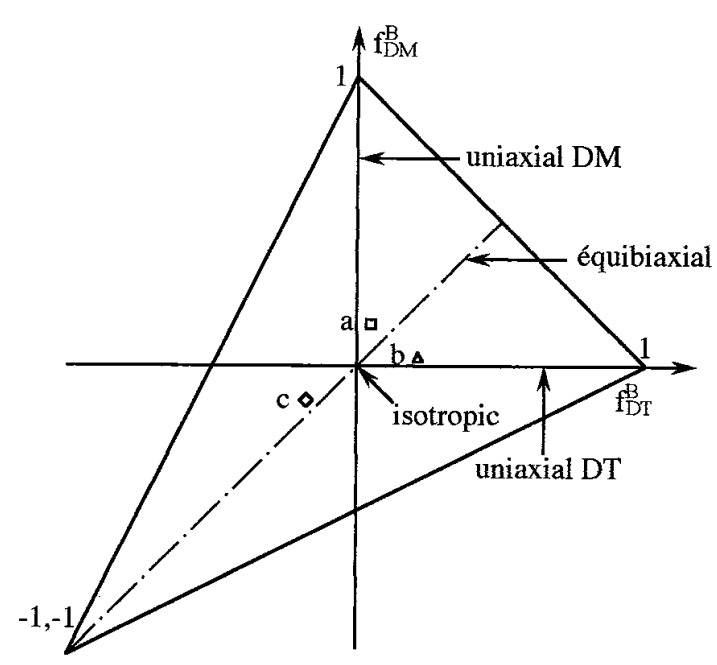

Figure 2 - Definition of the White-Spruiell orientation triangle.

Figure 2 - Définition du triangle d'orientation de White-Spruiell. 


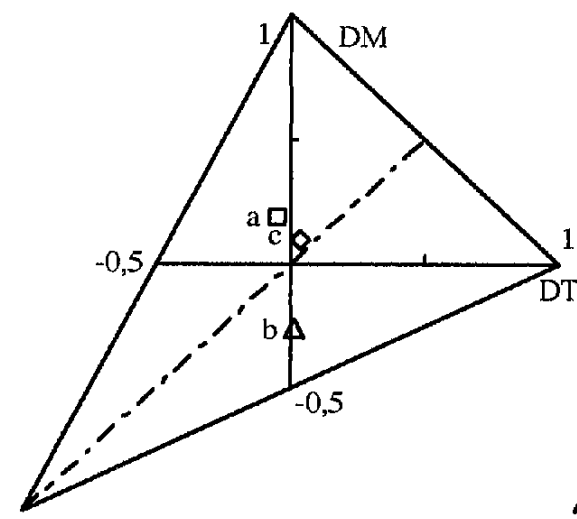

a)

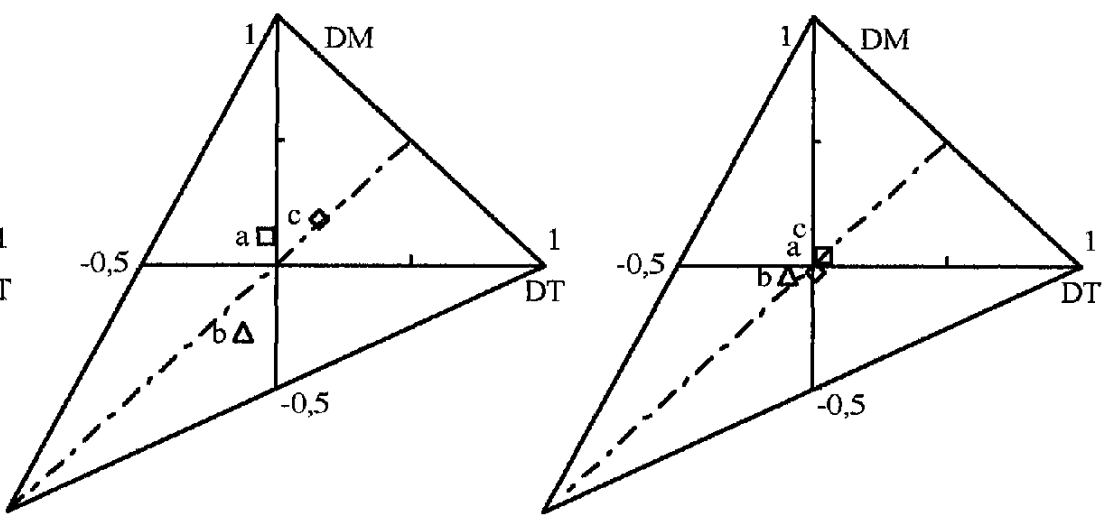

b) c)

Figure 3 - White-Spruiell orientation triangles for the polymer $\mathrm{A}$ of series $\mathrm{A}$ :

a) Bur=3.7, Dr=13.2, Flh=60 cm; b) Bur=3.6, Dr=13.6, Flh= $86 \mathrm{~cm}$; c) Bur=4.1, Dr=1.3, Flh = $37 \mathrm{~cm}$.

Figure 3 - Triangles d'orientation de White-Spruiell pour le polymère $A$ de la série $A$ :

a) Bur=3.7, Dr=13,2, Flh = $60 \mathrm{~cm} ; b) B u r=3,6, D r=13,6, F l h=86 \mathrm{~cm} ; c)$ Bur=4,1, Dr=1,3, Flh = $37 \mathrm{~cm}$.

The gold-coated external surfaces of series $C$ films have been observed by scanning electron microscopy (SEM) using a Philips XL 30 ESEM microscope. To enhance contrast, an angle of $40^{\circ}$ was imposed between the film normal and the incident beam. as by orientation triangles (comparison of fig. 5 , $a$ and $b$ ). 200 and 020 pole figures give the distribution of the a- and b-axes of the unit cell, respectively. For LDPE drawn specimens of series A and for LDPE specimens of series $B$ cooled with a single-flux air ring, they are characterized by a maximum of a-axis density along the machine direction DM

\section{RESULTS}

\section{Series A : the reference series}

The crystallographic texture of series A films has been extensively studied in (3). Therefore, only the main results will be recalled here. What is noticeable in this reference series is that for drawn specimens, even at high blow-up ratios, the representative points of the $\mathbf{a}-, \mathbf{b}-, \mathbf{c}$-axes in the orientation triangle are close to the DM axis (fig. 3a). This means that the macromolecular chains in the crystalline phase (c-axis) are oriented along DM and that the orientation is almost uniaxial.

The orientation tends to become equibiaxial when the freeze line height is increased (fig. 3b). A biaxial orientation is also observed for undrawn specimens, but the level of orientation is very weak (fig. 3c).

In contrast with the orientation of the crystalline one, the amorphous phase is oriented in the transverse direction DT (4).

\section{Series B : influence of cooling conditions}

The second series lays emphasis on the cooling conditions. With a simple-flux air ring, crystalline orientation is of the same type as in the first series, as attested by pole figures (fig. $4 a$ ) as well
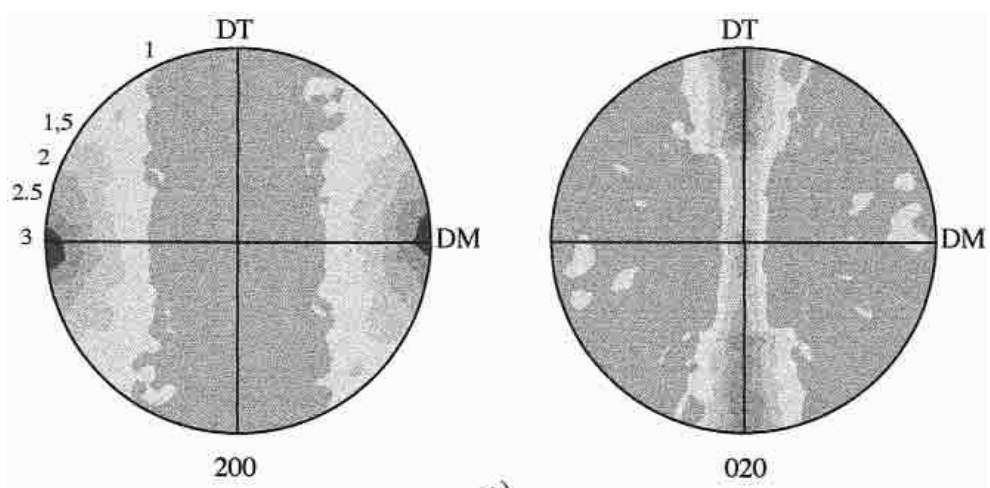

a)



200

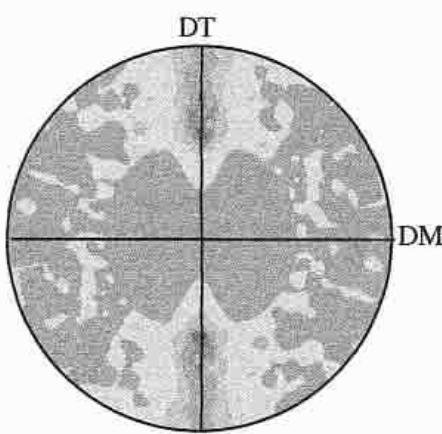

b)
Figure $4-200$ (on the left) and 020 (on the right) pole figures for a series $B$ LDPE cooled with a single flux (a) or a double-flux (b) air ring.

Figure 4 - Figures de pôles 200 (à gauche) et 020 (à droite) d'un PEBD de la série $B$ refroidi par un anneau à simple flux (a) ou à double flux (b). 
Figure 5 - White-Spruiell orientation triangles for the three series of films : a) series $A$; b) series $B$ LDPE, single-flux air ring ; $c)$ series $B$ LDPE, double-flux air ring ; d) series $B$ LLDPE, double-flux air ring ; e) series C.

Figure 5 - Triangles d'orientation de White-Spruiell des trois séries de films:

a) série $A$; b) série $B P E B D$, anneau à simple flux; $C$ ) série $B$ $P E B D$, anneau à double flux ;

d) série $B$ PEBDL, anneau à double flux ; e) série $C$.
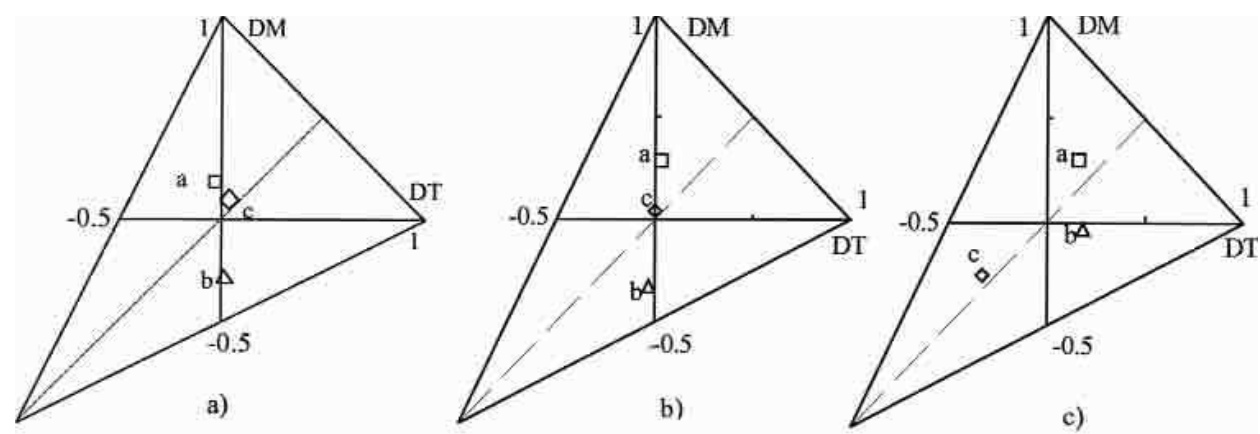

c)
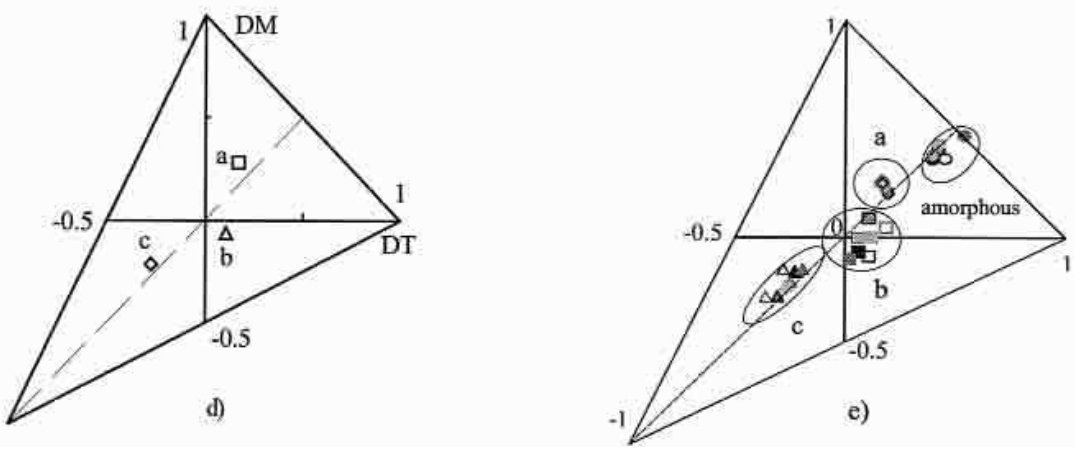

and $\mathbf{b}$-axes perpendicular to DM (fig. 4a). For both types of specimens, White-Spruiell triangles show a nearly uniaxial orientation, with a preferential orientation of the chain axis (c-axis) along DM (fig. 5, $a$ and b).

When a double-flux air ring is used, significant changes in the pole figures are observed (fig. $4 b$ ), and a new texture with the c-axis preferentially in the film thickness is revealed by the orientation triangles (fig. $5 c$ ). For given processing conditions, the nature of the material is of little influence : the same texture is obtained for a LDPE (fig. 5c) and a LLDPE (fig. 5d).
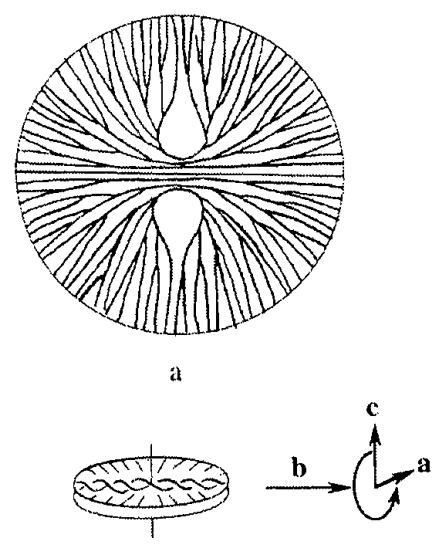

d

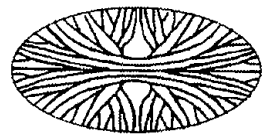

b
Figure 6 - Evolution of crystalline morphologies in polyethylene for increasing flow intensity : a) spherulite ; b) flattened spherulite ; c) sheaf-like texture ; d) and e) Keller's models with orientation of $\mathbf{a}-, \mathbf{b}-, \mathbf{c}$-axes in a radial lamella.

Figure 6 - Évolution des morphologies cristallines dans le polyéthylène pour des écoulements d'intensité croissante : a) sphérolite ; b) sphérolite aplati ; c) disque à section axiale en forme de gerbe ; d) et e) modèles de Keller avec orientation des axes $\boldsymbol{a}, \boldsymbol{b}$ et $\boldsymbol{c}$ dans une lamelle radiale.

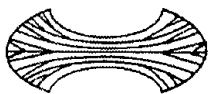

$c$

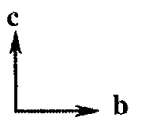

\section{Series C : different LLDPE}

This series compares LLDPE with different chemical structures, but transformed in the same processing conditions. Due to these changes in chemical structure, inducing for instance differences in the relaxation times (6), the quantitative of orientation are different from one polymer to anoth the same features as in series B for specimens cooled with a double-flux air ring (fig. 5e) : almost isotropic distribution of $\mathbf{b}$-axes, and c-axes preferentially in the film thickness. The amorphous chains are, for their part, isotropically located in the film plane (fig. 5e).

\section{DISCUSSION}

Figures $3 a, 5 a$ and $5 b$ show that the crystalline texture is close to a uniaxial orientation along DM, even though the degree of orientation of the c-axes is weak (their representative point is near the origin of the orientation triangle). As $\mathbf{a}, \mathbf{b}$ and $\mathbf{c}$ are orthogonal, these figures also imply that the texture obtained cannot be reduced to a simple monocrystalline one and that specific morphological models applied in polymer physics must be used. When flow intensity increases, the following sequence of morphologies can be expected (fig. 6) : 


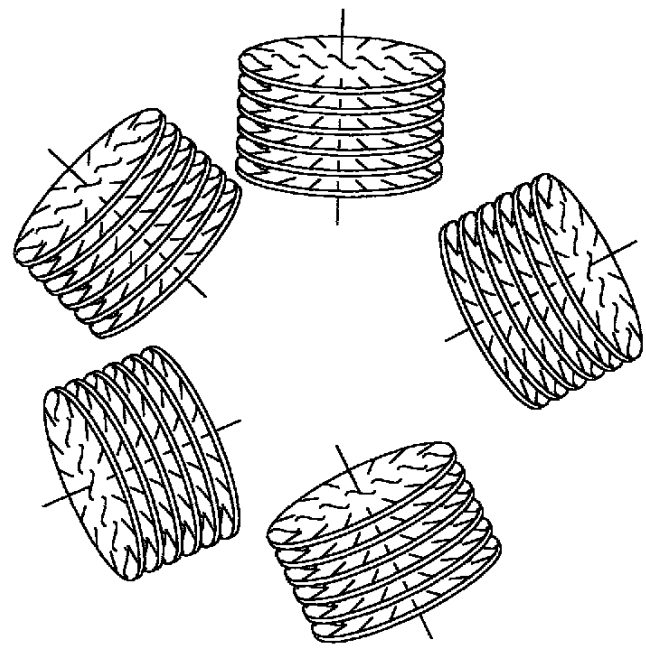

Figure 7 - Model proposed for describing crystalline morphologies in a film with an equibiaxial orientation (after (15)).

Figure 7 - Modèle proposé pour décrire les morphologies cristallines dans un film ayant une orientation équibiaxiale (d'après (15)).

- spherulites, i.e., spherical arrays of radiating crystalline lamellae (here schematically represented as dark lines), separated by amorphous phase (fig. 6a) ;

- spherulites deformed into ellipsoids (fig. 6b) ;

- sheaf-like textures (14) (fig. 6c);

- row-nucleated morphologies or cylindrites $(18,19)$. In fact, the organization of matter is the same as in spherulites, but with a cylindrical symmetry instead of a spherical one. Two variants of the model exist : Keller I with twisted lamellae at low stress (fig. 6d), and Keller II with flat lamellae at high stress (fig. 6e).

Each model corresponds to a given distribution of the $\mathbf{a}-, \mathbf{b}$ c-axes and consequently to reference states of orientation characterized by typical triangular diagrams. By comparing experimental results and ideal orientation situations, we found that the sheaf-model was a good candidate to describe the microstructure (3). In this case, it is possible to propose a realistic morphological texture associated with the observed crystallographic texture.

The situation is more complicated in biaxial cases like those described in figures $3, b$ and $c$. As an example, some authors (15) have proposed a model consisting of arrays of row-nucleated morphologies randomly distributed in the film plane (fig. 7 ).

The crystalline texture observed in films of series B cooled with a double-flux air ring (fig. 5, $c$ and $d$ ) and in all the films of series $C$ (fig. $5 e$ ) and characterized by a preferential orientation of the $\mathbf{c}$-axis in the film thickness is original and cannot be accounted for by the models of figures 6 and 7 . As a consequence, the classical and convenient procedure consisting in establishing a link between the crystalline orientation as determined by X-ray diffraction and a morphological model fails for these films. Therefore, the only solution is to observe the organization of the lamellae at the microscopic level. Figure 8 shows the SEM micrographs of the surface of the series $C$ films, from the least (top left) to the most oriented (bottom) one. A clear difference is observed between these extreme situations : globular spheruliticlike morphologies on one hand, and stacks of lamellae on the other hand, with a progressive variation in between. This evolution is accompanied by a variation of the crystalline orientation, as shown by figure $5 e$. Nevertheless, the changes in the orientation factors seem relatively weak compared to the drastic morphological changes. Furthermore, the apparent spherulitic texture is not associated with isotropy, and the stacks of twisted lamellae do not correspond to Keller I model. Consequently, the apparent discrepancy between crystallographic and morphological textures remains an open problem. This discrepancy has been also emphasized in other recent work (20).

\section{- CONCLUSION}

The crystalline orientation of a great number of polyethylene blown films differing by the nature of the polymer and the processing conditions has been investigated by X-ray diffraction. In some of them, the chain axes are preferentially oriented along the machine direction and the crystallographic texture is nearly uniaxial. In such a case, the orientation observed can be correlated to classical morphological models such as sheaf-like textures or row-nucleated morphologies.

Conversely, textures exhibiting a c-axis in the specimen thickness are original and until now no satisfactory morphological model has been proposed for their interpretation. This interpretation requires a careful observation of the lamellar organization by scanning or transmission electron microscopy as well as atomic force microscopy. This observation should lead to a quantification of the morphological texture in terms of the following parameters : orientation of the growth directions of the lamellae (b-axes in polyethylene), degree of twisting or bending of the lamellae. Such an analysis could reduce the apparent discrepancy between orientation and morphology, taking into account that these crystallographic and morphological data are of prime importance for a scientific understanding of the film properties.

\section{Acknowledgements}

This work has received financial and technical support from Elf-Atochem and BP Chemicals. The authors thank Gabriel Monge for his valuable help in X-ray measurements.

\section{references}

(1) HAUDIN (J.-M.), MONASSE (B.) - Structure and morphology of semicrystalline polymers. Structure development during polymer processing, eds. A.M. Cunha and S. Fakirov, Kluwer Academic Publishers, Dordrecht (2000), p. 47-67.

(2) PIANA (A.) - Étude des relations entre mise en forme, orientation et rétraction dans des films de polyéthylène basse densité réalisés par soufflage de gaine. Thèse, École des Mines de Paris, Sophia Antipolis (1984). 

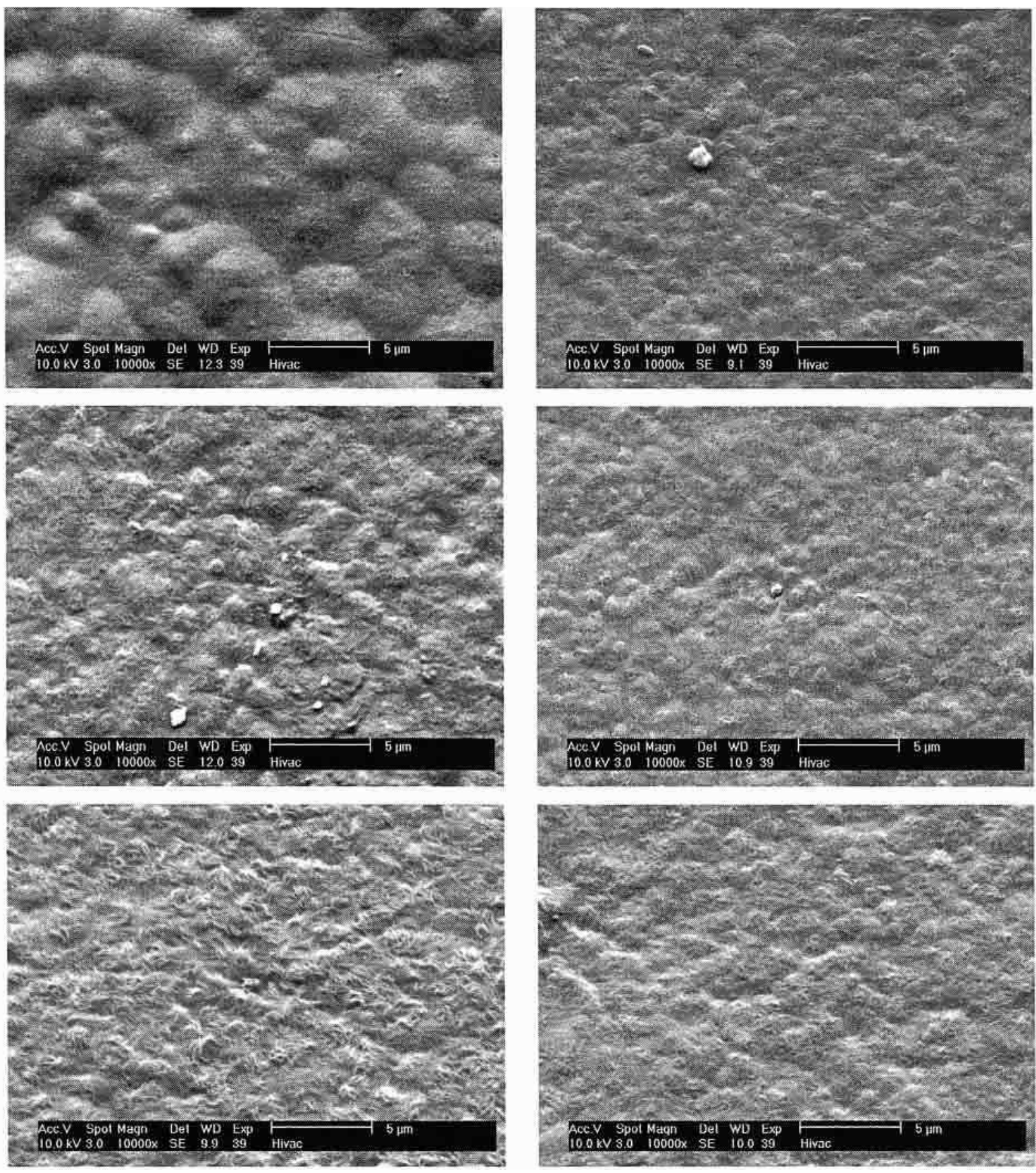

Figure 8 - Observation by SEM of the seven films of series $\mathrm{C}$.

Figure 8 - Observation par microscopie électronique à balayage des sept films de la série $C$.

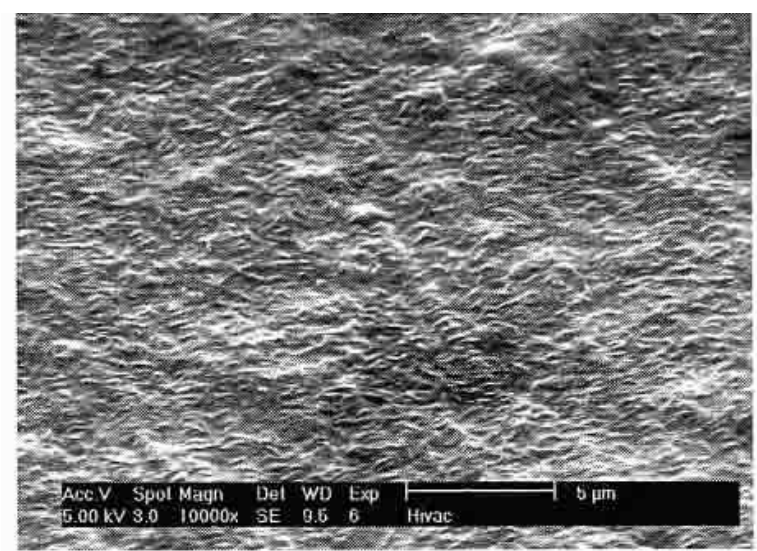


(3) HAUDIN (J.-M.), PIANA (A.) MONASSE (B.), MONGE (G.), GOURDON (B.) -Étude des relations entre mise en forme, orientation et rétraction dans des films de polyéthylène basse densité réalisés par soufflage de gaine. II. Orientation de la phase cristalline. Ann. Chim. Sci. Mat., 24 (1999), p. 555-580.

(4) HAUDIN (J.-M.), PIANA (A.), MONASSE (B.), GOURDON (B.) - Étude des relations entre mise en forme, orientation et rétraction dans des films de polyéthylène basse densité réalisés par soufflage de gaine. III. Orientation de la phase amorphe. Ann. Chim. Sci. Mat., 25 (2000), p. 53-64.

(5) ANDRÉ (J.-M.) - Modélisation thermomécanique et structurale du soufflage de gaine de polyéthylènes. Thèse, École des Mines de Paris, Sophia Antipolis (1999).

(6) BELLET (G.) - Relations structure - propriétés optiques et mécaniques de films de polyéthylène basse densité linéaire mis en œuvre par soufflage de gaine. Thèse, École des Mines de Paris, Sophia Antipolis (1999).

(7) BUNN (C.W.) - The crystal structure of long-chain normal paraffin hydrocarbons. The "shape" of the $\mathrm{CH}_{2}$ group. Trans. Faraday Soc., 35 (1939), p. 482-491.

(8) LINDENMEYER (P.H.), LUSTIG (S.) - Crystallite orientation in extruded polyethylene film. J. Appl. Polym. Sci., 9 (1965), p. 227-240.

(9) DESPER (C.R.) - Structure and properties of extruded polyethylene films. J. Appl. Polym. Sci., 13 (1969), p. 169-191.

(10) MATSUMARA (T.) - Mechanism of crystallite orientation during film blowing process. Kobunshi Ronbushu (Eng. Ed.), 5 (1976), p. 529-543.

(11) MADDAMS (W.F.), PREEDY (J.E.) - X-ray diffraction orientation studies on blown polyethylene films. I. Preliminary measurements. J. Appl. Polym. Sci., 22 (1978), p. 2721-2737.

(12) MADDAMS (W.F.), PREEDY (J.E.) - X-ray diffraction orientation studies on blown polyethylene films. II. Measurements on films from a commercial blowing unit. J. Appl. Polym. Sci. 22 (1978), p. 2739-2749.
(13) MADDAMS (W.F.), PREEDY (LE.) - X-ray diffraction orientation studies on blown polyethylene films. III. High-stress crystallization orientation. J. Appl. Polym. Sci., 22 (1978), p. 2751-2759.

(14) HAUDIN (J.-M.) - Étude de la texture cristalline de gaines de polyéthylène basse densité réalisées à faibles taux de gonflage et de tirage. Ann. Chim. Fr., 5 (1980), p. 513-534.

(15) CHOI (K.J.), SPRUIELL (J.E.), WHITE (J.L.) - Orientation and morphology of high-density polyethylene film produced by the tubular blowing method and its relationship to process conditions. J. Polym. Sci. Polym. Phys. Ed., 20 (1982), p. 27-47.

(16) KWACK (T.H.), HAN (C.D.), VICKERS (M.E.) - Development of crystalline structure during tubular film blowing of lowdensity polyethylene. J. Appl. Polym. Sci., 35 (1988), p. 363-389.

(17) WHITE (J.L.), SPRUIELL (J.E.) - Specification of biaxial orientation in amorphous and crystalline polymers. Polym. Engng. Sci., 21 (1981), p. 859-868.

(18) KELLER (A.), MACHIN (M.J.) - Oriented crystallization in polymers. J. Macromol. Sci. (Phys.), B1(I) (1967), p. 41-91.

(19) HILL (M.J.), KELLER (A.) - Direct evidence for distinctive stress-induced nucleus crystals in the crystallization of oriented polymer melts. J. Macromol. Sci. (Phys.), B3(1) (1969), p. $153-169$.

(20) LU (J.), SUE (H.J.), RIEKER (T.P.) - Morphology and mechanical property relationship in linear low-density polyethylene blown films. J. Mater. Sci., 35 (2000), p. 5169-5178. 